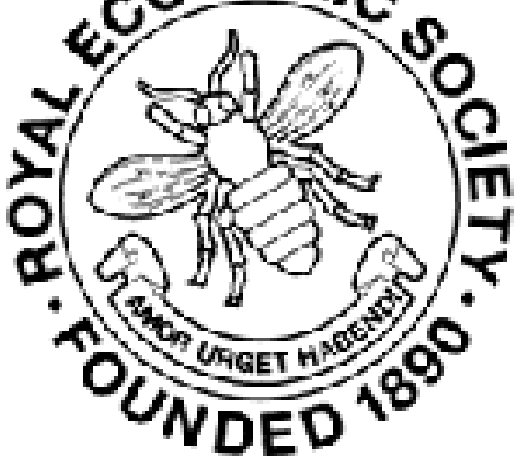

\title{
WILEY
}

Legislation of the Year 1898 in its Economic Aspects

Author(s): Montague Barlow

Source: The Economic Journal, Vol. 8, No. 32 (Dec., 1898), pp. 563-568

Published by: Wiley on behalf of the Royal Economic Society

Stable URL: http://www.jstor.org/stable/2957105

Accessed: 26-06-2016 00:30 UTC

Your use of the JSTOR archive indicates your acceptance of the Terms \& Conditions of Use, available at

http://about.jstor.org/terms

JSTOR is a not-for-profit service that helps scholars, researchers, and students discover, use, and build upon a wide range of content in a trusted digital archive. We use information technology and tools to increase productivity and facilitate new forms of scholarship. For more information about JSTOR, please contact support@jstor.org.

Royal Economic Society, Wiley are collaborating with JSTOR to digitize, preserve and extend access to The Economic Journal 
guarantees of the English system. They have been faced with the same problem as was found a serious difficulty here, to avoid hampering and discouraging existing organisations dealing with sickness and accidents, and yet to provide sufficient security against default on the part of those on whom was placed the legal liability to pay compensation. Much instruction will be afforded when the results of their efforts to solve the difficulty are known.

A. W. Fuux

\section{Legislation of the Year 1898 in its Economic Aspects.}

Of the 300 or more Public Bills submitted to the Parliament which came to an end on August 12th last, no more than sixty-two have become law, the last in the list being probably for many of our readers one of the most important, viz., "An Act to make further Provision with respect to the University of London."

Many of these enactments are of little or no interest from the economic point of view: the annual Army Act, for instance, which from year to year legalises the existence of a standing army, or the grants out of the Consolidated Fund for the services of the year.

Other Acts, though of economic interest for those immediately affected, are too restricted in scope to detain us. Such headings as "An Act to develop the Fisheries of Mussels in Ireland (Mussels, Periwinkles, and Cockles (Ireland) )," or "An Act to provide for the Punishment of Offences in Libraries," disclose measures of obvious utility, especially the latter, which is directed to remedying abuses and annoyances long complained of by readers at the British Museum and elsewhere ; but the economic condition of the Kingdom is not seriously involved in either measure.

Several of the Acts passed do, however, involve changes which cannot but affect to a very large degree the social and economic fabric of the country.

Of these in many ways the most important, as it certainly is the longest, is the Irish Local Government Act (61, 62 Vict., c. 37) ; and though its operation is naturally confined to one portion of the British Isles, it merits more than a passing notice here.

I. Irish Local Government Act (c. 37).-The Act consists of eight separate parts, the first part providing that "a Council shall be established in every administrative county, and be entrusted with the management of the administrative and financial business of that county, and shall consist of a Chairman and Councillors."

The number of Councillors and the electoral divisions in each county are left to a subsequent Order of the Local Government Board, but the Chairman of every rural District Council under this Act is to be an $e x$ officio member of the County Council (sec. 3).

To the County Council are transferred the following powers :-

$\mathrm{P}$ P 2 
1. The business generally of the old Grand Juries and of the county at large Presentment Sessions (sec. 4).

2. The business of the Guardians with respect to making, levying, collecting, and recovering the poor-rate, save in an urban county district (sec. 5).

3. Some miscellaneous duties under the Diseases of Animals Act. and the Explosives Act.

The new Councils are also to have the following powers: they are to be local authorities within the meaning of the Technical Instruction Acts (sec. 7) ; they are to decide what are main roads, and provide half the cost of their upkeep, the other half being borne by the county districts ; they are to provide and maintain sufficient accommodation for pauper lunatics (sec. 9), and may acquire land for this or any other purpose provided for by the Act.

The County Council must also contribute to infirmaries and fever hospitals situated within the county a sum not less than was contributed out of the County Cess formerly for the same purposes; further, the Council may appoint coroners and make bye-laws; but their powers in cases of exceptional distress are limited to presenting the case to. the Local Government Board, application first having been made to the County Council ; the Local Government Board may then authorise the Guardians to administer outdoor relief for a period not exceeding two months. The large boroughs, such as Dublin, Belfast, Cork, and Waterford, are to constitute administrative counties in themselves.

In addition to the administrative limits representing the county, there are, in accordance with Part II., to be both Urban and Rural District Councils ; ex officio Guardians are to cease in 1899, the District. Councillors taking their place in the rural districts; and persons chosen by the same method as the District Councillors are in the rural. districts, shall be elected Guardians in the urban districts. The powers: of these District Councils and Guardians include not only duties. transferred from Baronial Assessment Sessions, the old Grand Juries, and Guardians, e.g., as to poor rate, but also duties as to roads, duties. in connection with Burial Boards and under the Health Acts.

The qualification both for sittings and for voting alike in the case of County and District Councils is enrolment among the body of "Local Government electors," a term more fully defined in the general defining Section (109).

It is in the financial provisions that the Act shows the most ingenious. statesmanship, but it is impossible to deal with them in detail. The two main charges so well known in Irish Local Government, the County Cess and the poor rate, are in future to be payable by the occupier both in rural districts and in towns, and will be collected in one rate; taking 1896-97 as the standard year, any decrease of the rates will be to the advantage of the occupier, and any increase of course. the reverse. 
There is also an agricultural grant provided by the Act analogous to the English grant; each year from the Imperial Exchequer will be paid a sum equal to half the County Cess, and half the poor rate taken for the purposes of the Act to have been paid in respect of agricultural land in the standard year 1896-97; this grant so estimated will produce about $\$ 730,000.1$ Thus the main result of the Act is to substitute popularly elected Councils for the old nominated Grand Juries; there are not, however, in the Irish scheme any Parish Councils, as in the case of England and Scotland, the parish never having been an area of local administration in Ireland. The franchise is, in reality, the Parliamentary franchise, with the addition of peers and women; the qualifications will, in fact, be the same as for District and Parish Councils in England, with the omission, however, in the case of Ireland, of ministers of religion of all denominations.

Of more general Acts, the Prisons Act, the Habitual Drunkards Act, and the Vagrancy Act, are all of them important measures for dealing with the criminal classes and the prevention of crime.

II. Prisons Act (c. 41).--By this Act, Directors of Convict Prisons are amalgamated with the Prison Commissioners, and Boards of Visitors are established for every prison,-a most salutary innovation. With regard to the penalty of hard labour, attention is to be paid to the sex, age, health, industry, and conduct of the prisoners (sec. 4). Corporal punishment is now permissible only on the following conditions :-The prisoner must have been sentenced to penal servitude or hard labour or convicted of felony; he must have been guilty of mutiny in the prison or of gross personal violence; the Board of Visitors must order the punishment, and the Secretary of State must confirm the order. Prisoners not sentenced to penal servitude or hard labour are divided into three divisions; and prisoners imprisoned for default in payment of a debt, including a civil debt, shall not associate with criminal prisoners nor be compelled to wear prison dress. Remissions are granted for industry and good conduct while in prison; where imprisonment is for debt, part payment thereof to the governor secures a proportionate reduction in the term of imprisonment.

The Secretary of State is in future to have the power of regulating the prison life by means of rules, made subject to Parliamentary approval (sec. 2). This is, perhaps, the chief innovation under the Act, and will permit, instead of the hard and fast statutory rules scheduled in the Prisons Act, 1865, considerable variation in the treatment of prisoners and the introduction of ameliorations suggested by the Departmental Committee of 1875, such as better organisation of Prisoners' Aid Societies, a larger supply of books, and encouragement of healthy occupation.

III. Habitual Drunkards Act (c. 60).- The Act aims at the large class of criminals whose crimes are directly attributable to habitual

1 See Lord Ashbourne's speech when introducing the measure in the House of Lords, July 21, 1898 . Hansard, vol. 62, p. 538. 
drinking. The treatment so far accorded to the "Jane Cakebreads" of the community has been a scandal ; repeated short terms of imprisonment up to seventy times seven, and far beyond, are no curatives for inebriety. Power is now given to the Home Secretary to establish inebriate reformatories and make regulations; apart from any such special regulations, the rules under the Prisons Acts (including the Act of 1898) are to apply, but with this difference, there is to be no corporal punishment.

To these reformatories the two following classes of persons may be sent :--(i.) persons convicted on indictment of an offence punishable with imprisonment or penal servitude, provided the Court is satisfied from the evidence that the offence was committed under the influence of drink, or that drunkenness was a contributing cause, and the offender admits, or is found by the jury to be a habitual drunkard; (ii.) any person who commits an offence of the usual "drunk and disorderly" type, and has been convicted three times before within the last twelve months of a similar offence. Both classes of offenders may be sent to the newly constituted reformatories, but in no case for a period longer than three years.

The costs of the new institutions are to be borne by the Treasury and the County and Borough Councils; and if the inebriate has property of his own, the expenses of his detention may be ordered by the County Court judge to be paid thereout.

The Act also amends the Habitual Drunkards Act, 1879; and the "retreats" provided under the earlier Act for drunkards voluntarily seeking admission are in future to be licensed by Borough and County Councils, and not by the justices. The maximum period in the "retreat" is now extended from one year to two.

IV. Vagrancy Act (c. 39).-By this Act every male person who trades in prostitution either by living wholly or in part on the earnings of prostitutes, or who persistently solicits for an immoral purpose in a public place is to be deemed a "rogue and vagabond" under the Vagrancy Act, 1824. The latter Act allows rogues and vagabonds to be imprisoned for three months with hard labour, and on a second conviction of the offence they are to be punishable as incorrigible rogues, and may be committed to Quarter Sessions ; the justices at Quarter Sessions may sentence incorrigible rogues to one year's imprisonment with hard labour: and order further, "if they think fit, that such offender(not being a female) be punished by whipping at such time and at such place, as according to the nature of the offence they in their discretion shall deem to be expedient." During the passage of the Act of this year, it was proposed to entirely abolish the power to whip incorrigible rogues ; but this power appears to be used with caution, and only to have been exercised seven times during the last five years. In cases such as those dealt with by the present Act, whipping is eminently a proper penalty.

Two Acts were passed during the year dealing with revenue matters, of these the most important was :- 
V. The Finance Act (c. 10).-This dealt with customs and excise, stamps, income tax, land tax, and estate duties. Under the first head the duties on tobacco are reduced; on cigars the duty is now to be $5 s$. the lb., on unmanufactured tobacco containing $10 \mathrm{lbs}$. or more of moisture in every $100 \mathrm{lbs}$. weight, $2 s$. 8d., if containing less than $10 \mathrm{lbs}$. of moisture, $3 s$. A tax of fourpence per lb. on tea is reimposed for a year. The "grogging" of casks which have contained spirits, i.e., the extraction of spirits absorbed in the wood, is forbidden. The income tax is retained at eightpence, but the partial relief from taxation of a portion of the income is carried up to incomes of $£ 700$.

Section 12 exempts from land tax all owners of land relieved from income tax on the ground of their income not exceeding $£ 160$; and Section 13 provides for the repayment of settlement duties in certain cases. The Act also allows any solicitor or barrister to appear and plead before the Income Tax Commissioners, either viva voce or by writing.

VI. The Revenue Act (c. 46) deals also with customs, stamps, and excise.

It prohibits the importation of fictitious postage stamps, and of the advertisements of foreign lotteries, with which the British public is so frequently inundated. The Commissioner of Customs is also empowered to require an account of diamonds imported, in the same way as he already may of imported bullion or coin. Certain additional exemptions from stamp duty are made, e.g., in the case of receipt given by an officer of a County Court for money received by him (Sec. 8). Brokerage cannot now be claimed by a broker who does not send the contract note to his principal. The Act originally contained clauses of considerable importance, largely extending remissions of taxation and regularising many which are in fact now made by the officials in practice, such as the remission of the landlord's income tax on the ground of irrecoverability of rent through agricultural depression (original Section 18); but these were cut out during the passage of the Bill through Parliament, apparently on the ground that sufficient power already existed of making such remission in exceptional cases.

Chapters 15 and 19 provide two short but useful measures:

VII. Societies' Borrowing Powers Act (c. 15) allows friendly societies registered under the Act of 1896 to borrow money at interest from their members or from other persons, provided that a rule to that effect is duly registered; provided also that the society has a rule that no part of its funds shall be divided amongst the members, and that all money lent to members shall be applied to such purposes as the society or its committee approve. Such societies could heretofore only borrow on the security of land, and this Act appears likely to reduce the burden of loans, and so largely extend the influence of friendly societies.

VIII. Poor Law Unions Association Act (c. 19) provides for the establishment of a central Poor Law Unions Association in England 
and Wales, and allows Board of Guardians, subject to the consent of the Local Government Board, to contribute a sum not to exceed $£ 5$ per annum to the Association, and to pay the expenses of two delegates to attend the Association. This Act follows the example already set in the case of District and County Councils ; and the co-operation and uniformity of policy which combined discussion at the central association will tend to secure, is nowhere more necessary than in the case of Boards of Guardians.

IX. The Benefices Act (c. 48) deals with certain well recognised abuses in the exercise by a patron of his advowson or right of patronage, i.e., the right to present a fit clergyman to the bishop as each vacancy arises. With a view to prevent clergymen owners buying livings so as to present themselves, certain restrictions are placed on the free sale of livings. Sales of next presentations are forbidden, all sales must be registered in the Diocesan Registry within a month, and sales by auction of an advowson, save when held in conjunction with a manor, are forbidden. Further, in order to penalise purchasers of advowsons where the incumbent is old, with a view to speedy occupancy, the bishop may refuse to institute a clergyman if at the date of the vacancy not more than one year has elapsed since the last transfer. These restrictions on the right of property seem entirely justified under the special circumstances.

Lastly, one measure of considerable social importance must be mentioned :-

X. The Vaccination Act (c. 49), based on the recommendations of Lord Herschell's Commission of 1896, practically abolishes compulsory vaccination (which has existed since 1853), though nominally leaving it undisturbed. Many Boards of Guardians have long refused to enforce the Act, and now a parent cannot be convicted more than onc e for refusal to have his child vaccinated (sec. 3). Further, if within four months from the birth of the child he satisfies two justices or a stipendiary magistrate that he conscientiously believes that vaccination would be prejudicial to the child's health, he shall not be liable to any penalty. At the same time every inducement is offered to overcome reasonable objections: the period of vaccination is extended from three months to six from birth, the public vaccinator must on parents' request visit the child's home, and glycerinated calf lymph is to be substituted for child lymph, so as to put a stop to the transmission of merely human diseases.

Montague Barlow

\section{The Report of the Committee on Indian Currency}

Iт must be admitted that the minutes of the evidence taken before the Indian Currency Committee are disappointing reading. When the Government decided to submit the Indian proposals to a committee of gentlemen possessing (with two exceptions) no expert knowledge of the 